\title{
вмJ Global Health Decolonising global health: where are the Southern voices?
}

To cite: Oti SO, Ncayiyana J. Decolonising global health: where are the Southern voices?BMJ Global Health 2021;6:e006576. doi:10.1136/ bmjgh-2021-006576

Handling editor Seye Abimbola

Received 10 June 2021 Accepted 15 June 2021

Check for updates

(c) Author(s) (or their employer(s)) 2021. Re-use permitted under CC BY-NC. No commercial re-use. See rights and permissions. Published by BMJ.

${ }^{1}$ The Secretariat, Network of Impact Evaluation Researchers in Africa, Nairobi, Kenya

${ }^{2}$ Panel of Movers, Global Health Decolonisation Movement in Africa, Nairobi, Kenya ${ }^{3}$ Department of Public Health Medicine, University of KwaZulu-Natal, Durban, South Africa

Correspondence to

Dr Samuel 0ji Oti

sam.oti@alumni.harvard.edu
As evidenced by a plethora of publications, webinars, and social media hashtags, the last year or two have seen an amplification of calls for the decolonisation of global health. ${ }^{1-5}$ These calls have largely been virtually echoed in the hallways of academic institutions in the Global North such as the London School of Hygiene and Tropical Medicine, Duke University and Harvard University. For reasons which we can only speculate about such as fear of retaliation or feelings of powerlessness, the voices of global health institutions and practitioners based in the Global South have largely been absent amidst the calls for decolonisation.

Nevertheless, the rising wave of discontent with the power imbalances that plague the practice of global health is, without doubt, long overdue. This is even more pertinent and timely given that the COVID-19 pandemic is exacerbating global health inequalities. ${ }^{6}$ For example, it is no secret that countries in the Global North which account for under $15 \%$ of the world's population have secured for themselves almost half of all COVID-19 vaccine doses that are currently available. ${ }^{7}$ Some global health practitioners have even gone as far as referring to this blatant power abuse by rich countries as 'vaccine apartheid' or 'vaccine nationalism'.

Overall, while there is consensus regarding the broad focus of this rising discontent, there are divergent views about the best approaches to achieving the decolonisation of global health. Some proponents have adopted a philosophical approach perhaps seeking to ensure that the decolonisation movement is conceptually and theoretically grounded. ${ }^{8}$ Others have adopted a more pragmatic approach, for example, calling for a set of actions and metrics to hold global health institutions and practitioners more accountable. ${ }^{9}$ At the other extreme are those that are sceptical about decolonisation and even cynical about the semantics of the word itself. ${ }^{10}$

\section{Summary box}

In the last year or two, there have been growing calls for the decolonisation of global health.

- These calls recognise the fundamental need for global health institutions and practitioners to dismantle the persistent structural inequities perpetuated by global health's colonial heritage.

- However, these calls for decolonisation have largely been led by global health practitioners based at institutions in the Global North.

- At face value, it appears that global health institutions and practitioners in the Global South have not been visible or vocal amidst the calls for decolonisation.

- In this commentary, we address this misconception by highlighting recent efforts of global health practitioners in Africa, which emphasise pragmatic approaches aimed at decolonising global health.

Despite this apparent lack of coherence, it is encouraging that these conversations are even happening at all. Just like in the sphere of technological discovery and innovation, there is almost always a period of chaotic experimentation preceding the emergence of what is known as the 'dominant design'.11 It is therefore reasonable to anticipate that at some point in the future, the global health decolonisation movement will be characterised by its own dominant design-that is, a coherent set of principles, approaches and tools.

However, for those of us in the Global South who continue to endure the suffocating legacy of colonialism in global health, we simply cannot wait for the emergence of a dominant design. We simply cannot wait for the reimagining and rebuilding of the global health field as has been called for by some of our counterparts in the Global North. Therefore, we have decided to throw ourselves headfirst into the sphere of pragmatic action rather than wait on a dominant design.

Specifically, we have heeded the call to volunteer some of our time to become members of the Panel of Movers under the auspices of the Global Health Decolonisation Movement in 
Table 1 Snapshot of pragmatic approaches to decolonising global health

\section{Common manifestations of coloniality}

Ways to decolonise

Global and multinational organisations

Your decisions about who gets hired or promoted discriminate against people whose credentials or expertise are obtained in Africa.

Use blind or anonymous recruitment platforms (such as beapplied.com) and processes. Train your hiring managers to challenge their implicit biases constantly and consciously. Be aware that traditional recruitment considerations such as salary history and letters of recommendation often reflect and perpetuate biases against Africans and UIGH persons. Determine your job evaluation criteria thoughtfully and deploy methods such as holistic review methods in shortlisting candidates.

\section{Individual practitioners}

You consciously or subconsciously believe in the unidirectional flow of expertise from HIC to African and UIGH practitioners or organisations.

Reject 'saviourism' in all its manifestations. For example, refuse to be part of collaborations that do not give equal opportunity and reward to the contributions of your African and UIGH counterparts.

Grant-making organisations and funding agencies

Your funding criteria explicitly or implicitly require African and UIGH researchers to collaborate with HIC researchers, even if they do not need or want to.

Your funding opportunities should avoid language that overtly or covertly coerces African and UIGH practitioners into collaborations with HIC counterparts. Emphasise that African and UIGH practitioners should enter such collaborations entirely on their own and without fear that they will be penalised or overlooked for not doing so. If your institution is required by its mandate to include HIC practitioners, then you must take additional steps to ensure collaborations that are authentic and equitable. For example, scrutinise how budgets and authorships are distributed between the HIC and African or UIGH applicants.

\begin{tabular}{|c|c|}
\hline \multicolumn{2}{|l|}{ Academic and training institutions } \\
\hline $\begin{array}{l}\text { Africans are under-represented among your faculty, staff and } \\
\text { students. In fact, it is rare for an African or UIGH person to hold } \\
\text { tenure or other positions of significance at your institution. }\end{array}$ & $\begin{array}{l}\text { Recognise that there is evidence that diverse teams advance scholarly } \\
\text { environments. Set targets and take deliberate steps to diversify your institution or } \\
\text { group. Train your selection committees in best practices for improving diversity } \\
\text { such as holistic review methods. }\end{array}$ \\
\hline \multicolumn{2}{|l|}{ Scientific journals and publishers } \\
\hline $\begin{array}{l}\text { You prefer peer reviewers from } \mathrm{HIC} \text { and allow them to provide } \\
\text { aggressive and disparaging feedback to submissions from African } \\
\text { and UIGH practitioners. }\end{array}$ & $\begin{array}{l}\text { Editors must monitor and moderate feedback provided by reviewers particularly } \\
\text { to African and UIGH authors. Editors encountering biased or disrespectful reviews } \\
\text { should over-rule them and assign alternate reviewers to the submission. }\end{array}$ \\
\hline
\end{tabular}

Reproduced with permission from: Global Health Decolonisation Movement in Africa. Pragmatic Approaches to Decolonising Global Health in Africa: A guide for global health practitioners and organisations in High-Income Countries. Feb 2021. https://ghdmafrica.org/wp-content/uploads/2021/02/GHDM_brochure_web.pdf (accessed 1 Jun 2021)

HIC, High Income Country; UIGH, under-represented in global health.

Africa or GHDM-Africa. ${ }^{12}$ The GHDM-Africa is all about pragmatism. It has developed a framework that provides what it calls 'common-sense approaches' to decolonising global health. Table 1 shows a snapshot of this framework. As inaugural members of the Panel of Movers, we have accepted the task of actualising GHDM-Africa's mission of contributing to increasing the power and influence of Africans in global health practice.

By joining this pragmatism-first movement, we risk criticism from those who perhaps desire more transformative or systemic approaches. We also risk the scorn of those who do not even subscribe to the idea of or need for decolonisation in the first place. Just like the \#BlackLivesMatter movement was rebuffed cynically with \#AllLivesMatter, we anticipate that the \#DecoloniseGlobalHealth movement will continue to be met with resistance.

Nevertheless, we are committed to this movement because we believe that GHDM-Africa's calls for pragmatic approaches to decolonising global health are grounded in the fundamental principles of diversity, equity and inclusion. In our opinion, the pragmatic translation of these principles into actionable recommendations does not need justification or elaborate theoretical grounding because they embody the essence of human decency. Therefore, we strongly support GHDM-Africa's practical guidance to global health practitioners and institutions in the Global North regarding what they can and must do to decolonise global health.

Of course, we have no way of guaranteeing that anyone will heed to our calls for pragmatic action, nor do we know for sure that the implementation of such actions will lead to sustainable change. We indeed acknowledge that further thought will need to go into implementing some of the recommendations in GHDM-Africa's framework. For example, the framework recommends that global health organisations should use holistic review methods when recruiting employees to reduce hiring bias against Africans and other persons who are underrepresented in global health. Holistic review methods are not widely used and will require further validation in real-world contexts. ${ }^{13}$ We also know that questions will be raised about the effectiveness of some recommendations. For example, will training global health practitioners from the Global North on implicit bias or cultural sensitivity really lead to tangible changes in how they work with their counterparts from the Global South?

Imperfections aside, we believe that GHDM-Africa's framework will prove its utility to those who are willing to at least embrace the spirit behind it. However, its practicality should not be misconstrued as simplicity. We make 
no claims regarding how easy it might be to implement the framework. For example, the framework calls on academic institutions in the Global North to embark on a curriculum renewal drive that incorporates transformative learning and cognitive justice approaches into global health education. This means that global health curricula could include the fundamentals of colonial theory and the sociohistorical impacts of colonialism and coloniality in the developing world. Attempting such radical reform will be no walk in the park. Just like we have seen with the resistance to the inclusion of critical race theory in American schools, ${ }^{14}$ we know that there will be resistance to reforming the global health curricula.

Circling back to the central question of this commentary which asks: where are the Global South voices in this burgeoning global health decolonisation movement? Our response is that we are right here. We have chosen the uncertain but necessary path of moving from rhetoric to action. We simply do not have the luxury or privilege to do otherwise. We call on global health practitioners and institutions across the world to join us in this journey. Twitter Samuel 0ji Oti @DrSam_0ti

Contributors SOO conceptualised the commentary and wrote the first draft of the manuscript. JN critically reviewed and revised the manuscript.

Funding The authors have not declared a specific grant for this research from any funding agency in the public, commercial or not-for-profit sectors.

Competing interests None declared.

Patient consent for publication Not required.

Provenance and peer review Commissioned; internally peer reviewed

Data availability statement There are no data in this work.

Open access This is an open access article distributed in accordance with the Creative Commons Attribution Non Commercial (CC BY-NC 4.0) license, which permits others to distribute, remix, adapt, build upon this work non-commercially, and license their derivative works on different terms, provided the original work is properly cited, appropriate credit is given, any changes made indicated, and the use is non-commercial. See: http://creativecommons.org/licenses/by-nc/4.0/.

\section{REFERENCES}

1 Abimbola S, Pai M. Will global health survive its decolonisation? Lancet 2020;396:1627-8.

2 Hirsch LA. Is it possible to decolonise global health institutions? Lancet 2021;397:189-90.

3 Büyüm AM, Kenney C, Koris A, et al. Decolonising global health: if not now, when? BMJ Glob Health 2020;5:e003394.

4 Eichbaum QG, Adams LV, Evert J, et al. Decolonizing global health education: rethinking institutional partnerships and approaches. Acad Med 2021;96:329-35.

5 Lawrence DS, Hirsch LA. Decolonising global health: transnational research partnerships under the spotlight. Int Health 2020;12:518-23.

6 Bambra C, Riordan R, Ford J, et al. The COVID-19 pandemic and health inequalities. J Epidemiol Community Health 2020;74:964-8.

7 Mirza A, Rauhala E. Here's just how unequal the global coronavirus vaccine rollout has been. The Washington Post, 2021. Available: https://www.washingtonpost.com/world/interactive/2021/ coronavirus-vaccine-inequality-global/ [Accessed 01 Jun 2021].

8 Affun-Adegbulu C, Adegbulu O, Global D. Decolonising global (public) health: from Western universalism to global pluriversalities. BMJ Glob Health 2020;5:e002947.

9 Khan M, Abimbola S, Aloudat T, et al. Decolonising global health in 2021: a roadmap to move from rhetoric to reform. BMJ Glob Health 2021;6:e005604.

10 Khan T. Decolonisation is a comfortable buzzword for the aid sector., 2021. Open democracy. Available: https://www.opendemocracy.net/ en/decolonisation-comfortable-buzzword-aid-sector/ [Accessed 01 Jun 2021].

11 Srinivasan R, Lilien GL, Rangaswamy A. The emergence of dominant designs. J Mark 2006;70:1-17.

12 Global health Decolonisation movement in Africa. GHDM-Africa: panel of Movers. Available: https://ghdmafrica.org/our-movers/ [Accessed 01 Jun 2021].

13 Wilson MA, Odem MA, Walters T, et al. A model for holistic review in graduate admissions that decouples the GRE from race, ethnicity, and gender. CBE Life Sci Educ 2019;18:ar7.

14 Sawchuk S. What is critical race theory and why is it under attack? 2021. EdWeek. Available: https://www.edweek.org/leadership/ what-is-critical-race-theory-and-why-is-it-under-attack/2021/05 [Accessed 01 Jun 2021]. 